Khazanah: Jurnal Studi Islam dan Humaniora

ISSN: 0215-837X (p); 2460-7606 (e), Vol. 19 (1), 2021, pp. 61-82

DOI: 10.18592/khazanah.v19i1.4150

Submit: 29/11/2020 Review: 01/01/2021 Publish: 30/06/2021

\title{
REKONSILIASI ISLAM DAN SAINS DALAM PERSPEKTIF NIDHAL GUESSOUM
}

\author{
Zulpa Makiah \\ Universitas Islam Negeri Antasari Banjarmasin \\ zulpamakiah@gmail.com
}

\begin{abstract}
This paper describes Nidhal Guessoum, who tried to reconcile the epistemic between the Islamic tradition and modern science. The method used is descriptive content analysis. Nidhal sees that efforts to build relations between religion and science are still simplistic. He seeks to uncover the deadlock between the science of religion and philosophy and to present the principles of reconciliation of Islam and science more completely and systematically. This reconciliation effort departs from his critique of the condition of education and Arab society as well as the Islamic world as a whole, as well as the developing thoughts on the relationship between religion and science, which are sometimes too simplistic, both Sardar's ijm li model, $i^{\prime} j$ z. an-Najjar model, and Islamization of al-Faruqi's model of knowledge. In Nidhal's view, these methods contain weaknesses, so those other alternatives are needed. The steps taken by Nidhal are to build a foundation for the creation of a harmonious relationship between science, religion and philosophy. He proposed a quantum approach through (1) the principle of no conflict between religion and science, (2) layered interpretation of the Qur'an, (3) theistic falsification.
\end{abstract}

Keyword: Reconciliation; Religion; Science

\begin{abstract}
Abstrak:Tulisan ini berupaya menjelaskan pemikiran Nidhal Guessoum yang berusaba melakukan rekonsiliasi epistemike antara tradisi Islam dan sains modern. Metode yang digunakan dalam membaca karya Nidhal adalah dengan menggunakan analisis isi (content analysis) secara deskriptif. Nidhal melihat upaya dalam membangun relasi antara agama dan sains masib bersifat simplistik. Nidhal berusaha menyingkap kebuntuan titik temu antara sains agama dan filsafat serta menghadirkan prinsip-prinsip rekonsiliasi Islam dan sains secara lebih lengkap dan sistematis. Upaya rekonsiliasi ini berangkat dari kritiknya terhadap kondisi pendidikan dan masyarakat Arab serta dunia Islam secara keseluruhan, juga terhadap pemikiran-pemikiran yang berkembang mengenai bubungan antara agama dan sains yang terkadang terlalu simplistik, baik model ijmäli Sardar, model i’jā̄ an-Najjar, maupun Islamisasi pengetahuan model al-Faruqi. Metode-metode itu dalam pandangan Nidhal mengandung kelemahankelemahan sehingga diperlukan alternatif lain. Langkah yang dilakukan Nidhal adalah membangun landasan terciptanya bubungan yang harmonis diantara sains, agama dan filsafat. Nidhal mengusulkan pendekatan kuantum melalui: (1) prinsip tidak ada pertentangan antara agama dan sains; (2) penafsiran berlapis terhadap al-Qur'an; (3) falsifikatif teistik.
\end{abstract}

Kata kunci: Rekonsiliasi; Agama; Sains

\section{Pendahuluan}

Hubungan antara agama dan sains secara umum seringkali problematik. Dalam tradisi Kristen awal abad pertengahan ada ketidakharmonisan antara saintis dan agamawan. Frederic Meyer mengungkapkan ada tiga hal. Pertama: munculnya doktrin agama sehingga cenderung memicu perpecahan. Kedua, adanya kebutuhan membentengi ajaran Kristen dari serangan luar terutama filsafat Yunani yang 
menganggap Kristen sebagai agama penuh takhayul sehingga kebenarannya lebih rendah dari filsafat. Ketiga, kebutuhan akan adanya penjelasan rasional dan sistematis atas doktrin Kristen guna didakwahkan kepada kaum intelektual. ${ }^{1}$ Dominasi Gereja atas pengetahuan sampai pada tindak kekerasan pada ilmuwan yang berbeda paham, sebagaimana perlakuan terhadap ilmuwan perempuan bernama Hypatia yang dibunuh oleh segerombolan fanatik.

Dobrakan terhadap pemahaman agama datang dari para ilmuwan Copernicus (1473-1543) melalui paham heliosentris yang berupaya merevolusi keyakinan astronomis tradisional yang diyakini gereja selama ribuan tahun. ${ }^{2}$ Copernicus menunjukkan lewat penelitian secara matematis bahwa matahari sebagai pusat alam semesta. Pendapat ini didukung oleh Galileo-Galilei (1564-1642) setelah menemukan teleskop pada tahun $1610 .{ }^{3}$ Karena otoritas gereja begitu kuat, maka berujung pada inkuisisi yang dilakukan atas Galileo. Setelah itu muncullah Kepler (1571-1630) yang juga mendukung teori Copernicus, kemudian Newton (1642-1727) yang melahirkan revolusi pemikiran yang menjadikan sains sebagai bagian dari kebudayaan Barat. ${ }^{4}$

Ian G. Barbour mengatakan terdapat empat varian hubungan agama dan sains yaitu konflik, independen, dialog dan integrasi. Dalam hubungan konflik, agama dan sains saling menegasikan dan masing-masing mengklaim kebenarannya sendirisendiri. Hubungan independensi dimana ada pengakuan terhadap eksistensi masingmasing. Dalam hubungan dialog, antara sains dan agama terdapat hal-hal yang dapat didialogkan sehingga bisa saling mendukung. Sedangkan hubungan integrasi yaitu agama bisa memanfaatkan temuan-temuan sains mutakhir dalam rangka merumuskan konsep teologisnya sehingga agama dan sains terintegrasi. ${ }^{5}$

Diskursus mengenai Islam dan sains sudah diperbincangkan oleh banyak tokoh dan pemikir muslim diantaranya Ziauddin Sardar ${ }^{6}$, Sayyid Hosen Nashr ${ }^{7}$,

${ }^{1}$ Maimun Syamsuddin, Integrasi Multidimensi Agama Dan Sains: Analisis Sains Islam Naquib alAttas Dan Mebdi Golshani (Yogyakarta: IRCiSoD, 2012).), 49-50.

${ }^{2}$ Kees de Groot, "The Church in Liquid Modernity: A Sociological and Theological Exploration of a Liquid Church," International Journal for the Study of the Christian Church 6, no. 1 (March 1, 2006): 91-103, https://doi.org/10.1080/14742250500484469.

${ }^{3}$ Avner Ben-Zaken, "The Heavens of the Sky and the Heavens of the Heart: The Ottoman Cultural Context for the Introduction of Post-Copernican Astronomy," British Journal for the History of Science; Norwich 37, no. 132 (March 2004): https://search.proquest.com/docview/215730323/abstract/6831679491C2483EPQ/17.

${ }^{4}$ Maimun Syamsuddin, 54.

5Ian G. Barbour, When Science Meets Religion: Enemies, Strangers, or Pathners? (New York: HarperCollins, 2000). Lihat Zainal Abidin Bagir (ed), Integrasi Ilmu Dan Agama: Interpretasi Dan Aksi (Bandung: Mizan Media Utama, 2005).), 22.; Lihat M. Amin Abdullah, Multidisiplin, Interdisiplin \& Transdisiplin, Metode Studi Agama \& Studi Islam Di Era Kontemporer (Yogyakarta: IB Pustaka, 2020).

${ }^{6}$ Ziauddin Sardar (1951), menguasai berbagai spektrum kajian yang luas dari sains, teknologi, filsafat, agama, budaya, teori postmodernisme, seni, studi masa depan, kebijakan politik dan lain-lain. Ia mengkritik metode sains modern dan rasionalis garis keras. Sardar mengkritik apa yang dilakukan Barat yaitu memutuskan akar warisan Islam dari sains dan dari pembelajaran Eropa, merekayasa sejarah dengan membuat semua sejarah sains Islam dan menyangkal keberadaan sains dalam Islam. Lihat Nidhal Guessoum, Islam Quantum Question, Reconciling Muslim Tradition and Modern Science (London- 
Abdussalam ${ }^{8}$, Mehdi Golshani, ${ }^{9}$ Al-Faruqi ${ }^{10}$ dan lain-lain. Para pemikir muslim kontemporer memiliki beragam pandangan dan posisi yang sangat berbeda terkait sains secara umum, begitu pula dengan wacana sains islami, kita menjumpai beragam proposisi-proposisi tentang hal tersebut. ${ }^{11}$

Ada beberapa aliran pemikiran yang dapat diidentifikasi dalam lanskap kebudayaan muslim terkait dengan sains. Ada aliran yang sangat mistis (aliran gnostik Nashr, pendekatan tradisional dan sakral dalam pengetahuan dan sains) hingga yang sekular, universalis dan konvensionalis (penekanan Abdus Salam bahwa sains bersifat universal dan objektif, sehingga tidak ada yang namanya sains Islami, sains Cina, sains Yunani). Mazhab ijmati model Sardar yang berasumsi bahwa sains islami bisa menjadi universal meskipun terinspirasi dari prinsip-prinsip Islam, menurut Nidhal masih belum membumi dan memiliki konsep yang kuat. Ada al-Najjar dengan metode i’jažnya. Metode-metode itu dalam pandangan Nidhal mengandung kelemahankelemahan sehingga diperlukan alternatif lain. ${ }^{12}$

New York: I.B. Tauris, 2011), 76-77. Sardar juga mengkritik sains Islami ala Nashr karena dipandang memuja simbolisme sains yang tersembunyi dan gaib. Sains Islam menurutnya bukan mengislamkan sains yang sudah dikenal saat ini, melainkan memikirkan sains yang sudah ada dalam sudut pandang Islam. Namun ia sendiri mendapat kritikan dari muslim tradisionalis karena dianggap sangat sedikit menggunakan dimensi spiritual Islam dan terlalu tertarik pada etika, kritik sains lingkungan dan dunia ketiga, bukan pada dasar-dasar metafisiknya.

${ }^{7}$ Sayyid Hosen Nashr (1932), seorang neo tradisionalis dan guru sufi, dengan metode Sains Islami (Islamic Science). Sains dalam pandangan Islam memiliki ciri-ciri khusus yang berbeda dengan sains dalam pandangan Barat yang materialis dan naturalis dan menolak dimensi spiritual manusia dan alam semesta. Nashr menggunakan istilah scientia sacra (pengetahuan atau sains sakral), yaitu pengetahuan sakral sebagai pengetahuan yang terletak di jantung setiap wahyu yang merupakan aplikasi pengetahuan suci berbagai bidang realitas, sebagai perjalanan menuju kesempurnaan realitas. Lihat Nidhal Guessoum., 105-107.

${ }^{8}$ Abdus Salam (1926), lahir di Pakistan, peraih Nobel, Ph. d dalam fisika teoritis, menyatakan tidak ada kontradiksi antara iman pribadi dan penemuan-penemuan sains yang dengannya manusia memahami alam dan jagat raya. Pandangannya sains bersifat universal, penerapannya dipengaruhi faktor budaya. Ia menolak gagasan sains Islami, karena doktrin penciptaan dari ketiadaan bersifat metafisis sehingga bukan merupakan lahan Islami.

${ }^{9}$ Mehdi Golshani (1939), fisikawan dan filsuf Iran, berpandangan sains modern adalah warisan peradaban Islam. Meraih Ph. d dalam fisika partikel dari university of California di Barkeley, memberi kontribusi besar mengenai interaksi sains dan agama. Lihat Nidhal Guessoum, Islam Quantum Question, Reconciling Muslim Tradition and Modern Science, 96.

${ }^{10} \mathrm{Al}-\mathrm{Faruqi}$, Islamisasi Sains atau Islamisasi pengetahuan, mengislamkan disiplin-disiplin ilmu, menghasilkan buku-buku universitas dan membangun ulang sekitar duapuluh disiplin ilmu agar sesuai dengan visi Islam. Membangun hubungan antara bidang-bidang pengetahuan tertentu dan prinsip-prinsip Islam. Melakukan lompatan atau inovasi dalam mensintesakan dasar-dasar peradaban Islam dengan pengetahuan kontemporer, dan mengarahkan berbagai pemikiran Islam menuju pencapaian model ilahiah atau teistik. Lihat Nidhal Guessoum, 119.

${ }^{11} \mathrm{M}$. Zainal Abidin, "Islam Dan Ilmu Pengetahuan: Diskursus Pemikiran Muslim Kontemporer," ULUMUNA 10, no. 2 (2006): 391-410.; Muhammad Zainal Abidin, "Dinamika Perkembangan Ilmu Dalam Islam Serta Statusnya Dalam Perkembangan Peradaban Modern," Jurnal Ilmu Ushuluddin 11, no. 1 (2012): 21-42.

${ }^{12}$ Nidhal Guessoum, Islam Quantum Question, Reconciling Muslim Tradition and Modern Science. 105-110, 125-129, 132-135.

Khazanah, Vol. 19 (1), 2021 
Dalam bukunya Islam Quantum's Question, Reconciling Muslim Tradition and Modern Science, Nidhal berupaya meninjau kesuksesan yang baru-baru ini dilakukan umat Islam dan menyingkap kebuntuan titik temu antara sains, agama dan filsafat serta menghadirkan prinsip-prinsip rekonsiliasi Islam dan sains secara lebih lengkap dan sistematis. Langkah yang dilakukan Nidhal adalah membangun landasan terciptanya hubungan yang harmonis antara sains, agama dan filsafat. ${ }^{13}$

Selanjutnya tujuan dari buku ini adalah memperkenalkan tokoh-tokoh yang telah berupaya dan menghidupkan kembali diskusi tentang peran dan status sains dalam masyarakat muslim. Selain itu Nidhal ingin menunjukkan bahwa sintesis harmonis antara sains modern dan Islam pada hakikatnya bisa diusahakan, dalam versi sains teistik, dimana Islam dapat bergandengan tangan dengan tradisi monotestik lainnya khususnya Kristen. Dengan melalui pembacaan yang masuk akal. Dengan model harmoni 'kuantum' (ganda) yang dipenuhi pengetahuan sains, filosofinya dan metode-metodenya yang tidak tunduk pada doktrin positivistik materialistik, seraya menjauh dari pendekatan tradisionalis dan menolak sikap ultra liberal, melainkan bersifat moderat dengan rekonstruksi yang cermat.

Karya akademik mengenai Nidhal Guessoum dilihat dari keterkaitan pemikirannya dengan implementasi pengembangan modul ajar IPA untuk kelas VII tingkat sekolah dikaji oleh A. Damayanti. ${ }^{14}$ Karya Achmad Khodari Soleh mengkaji pendekatan kuantum dalam integrasi agama dan sains. ${ }^{15}$ Ilyas Daud mengkaji pemikiran kosmologi Nidhal Guessoum. ${ }^{16}$ Sedangkan tulisan ini berupaya mengkaji pemikiran epistemologis Nidhal dalam kerangka hubungan antara Islam dan sains modern.

\section{Metode Penelitian}

Penelitian ini adalah termasuk library research (penelitian kepustakaan). Data diperoleh dari sumber kepustakaan, meliputi sumber utama berupa karya-karya dari Nidhal Guessoum dan karya lain yang mendukung untuk melihat pemikiran mengenai rekonsiliasi antara agama dan sains. Metode yang digunakan dalam membaca karya Nidhal adalah dengan menggunakan analisis isi (content analysis) secara deskriptif.

Langkah-langkah pencarian data dilakukan dengan mengkaji buku-buku yang sesuai dengan tema penelitian dengan memfokuskan kajian pada karya Nidhal Guessoum yang berjudul Islam Quantum's Question, Reconsiling Muslim Tradition and Modern Science, dan karya lainnya yang memiliki kedekatan dengan tema yang dikaji.

\footnotetext{
${ }^{13}$ Nidhal Guessoum, xxv.

${ }^{14}$ Khodari Soleh, "Pendekatan Kuantum Dalam Integrasi Agama Dan Sains," Jurnal Ulul Albab Volume.19, no. No.1 (2018).

${ }^{15}$ Khodari Soleh.

${ }^{16}$ Ilyas Daud, "Islam Dan Sains Modern (Telaah Pemikiran Nidhal Guessoum Dalam Karyanya Islam's Quantum Question Reconciling Muslim Tradition and Modern Science," Jurnal AlMutaaliyah, 2019.
} 
Tulisan ini mengkaji pemikiran epistemologis Nidhal dalam kerangka hubungan antara Islam dan sains modern.

\section{Pembahasan}

\section{Mengenal Nidhal Guessoum}

Nidhal Guessoum seorang guru besar Fisika dan Astronomi yang berusaha membangun jembatan (rekonsiliasi epistemik) antara tradisi Islam dan sains modern. Nidhal dilahirkan tanggal 6 September 1960 di Aljazair. Terlahir dari keluarga intelektual. Ayahnya adalah guru besar filsafat di Universitas Aljazair sekaligus seorang hafiz, lulusan dua universitas terkemuka dunia, yaitu Universitas Sorbonne, Paris dan Universitas Kairo Mesir. Ibunya pecinta sastra yang bergelar Master dalam bidang sastra Arab. ${ }^{17}$

Pendidikan dasarnya dilewatkan di Lycée Amara Rachid School, di Aljazair, yang menggunakan bahasa Arab dan Prancis sebagai bahasa pengantarnya. Pendidikan tingkat sarjana di Universitas Sains dan Teknologi Algeria, Aljazair, program Fisika Teoritis, lulus tahun 1982, dengan predikat lulusan terbaik. Pendidikan tingkat Master dan Doktor ditempuh di Universitas California, USA. Lulus Master bidang Fisika tahun 1984, dan selesai Doktor tahun 1988 dengan disertasi berjudul Thermonuclear Reactions of Light Nuclei in Astrophysical Plasmas. ${ }^{18}$

Selesai Doktor, Nidhal langsung mengambil program post-doctoral di pusat penelitian NASA, USA, tahun 1988-1990, di bawah bimbingan langsung Prof. Reuven Ramaty (1937-2001). Reuven Ramaty sendiri adalah tokoh di NASA, ahli bidang astronomi sinar gamma, astrofisika nuklir, dan sinar kosmik. Selesai postdoctoral, Guessoum pulang ke Aljazair dan menjadi dosen di Universitas Blida, Aljazair, tahun 1990-1994. Tahun 1994-2000, ia pindah ke Kuwait dan menjadi Asisten Profesor di College of Technological Studies, Kuwait. Tahun 2000, Nidhal pindah ke Uni Emirat Arab (UEA) dan menjadi Profesor penuh pada tahun 2008 di American University of Sarjah, pada Jurusan Fisika, Fakultas Art and Science.

Nidhal menghasilkan banyak karya tulis, baik berupa buku, proseeding seminar, hasil penelitian maupun jurnal internasional. Untuk buku yang populer di Indonesia, yaitu Islam's Quantum Question Reconciling Muslim Tradition and Modern Science. Karya-karya yang lain yaitu (1) Islam Big Bag ed Darwin: Les Quetions Qui Fachent, (2) Islam et Science: Comment Consilier Le Corant et La Science Moderne;(4). Reconcilier l'Islam et La Science Moderne; (5) Itsbât al-Shubûr al-Hilâliyah wa Musykilah al-Tawqîti al-Islâmi; (6) Qishshah al-Qawni: (7) Applications of Astronomical Calculations to Islamic Issues. Nidhal Guessoum, "Science, Education, Philosophy, and More".

\footnotetext{
${ }^{17}$ Nidhal Guessoum, Islam Quantum Question, Reconciling Muslim Tradition and Modern Science. xxiii ${ }^{18}$ Nidhal Guessoum.
} 
Pada akhir 1990 Nidhal baru mulai menekuni bidang sains, agama dan filsafat. Pertama-tama, Nidhal menjelajahi secara sistematis sains, agama, dan filsafat Barat. Ia membaca berbagai karya penting dari Barbour, Peacockem Polkinghorne, Ruse, dan lain-lain. Nidhal juga tidak melupakan filsafat Islam, dari al-Ghazali, Ibnu Rusyd sampai Iqbal dan Nasr. Pada tahun 2000 bersama koleganya Karim Meziane melakukan kerjasama perbandingan tiga variabel yaitu antara kosmologi yang dikembangkan filsuf muslim abad pertengahan, pemikir kontemporer Islam dan ilmu pengetahuan modern. Artikel ini menarik perhatian publik sehingga Nidhal banyak diundang ke berbagai lokakarya dan seminar mengenai hubungan sains dan Islam ${ }^{19}$

Menurut Nidhal benang merah dari semua karya intelektual dan pendidikan yang ia miliki adalah terdiri dari bagian-bagian yang satu sama lain saling terjalin berikut: 1) sains sangatlah penting dan relevan dengan Islam (dan dengan budaya lain), 2) sains dapat membantu menciptakan kemajuan bukan hanya secara material, melainkan juga secara intelektual, kultural dan religius 3) Sains terus berkembang dan teologi juga harus demikian. 4) Jika diperhatikan secara seksama tidak ada meterialisme murni yang menentang keterkaitan antara Islam dan sains. ${ }^{20}$

\section{Kegelisaban Nidbal Guessoum}

Nidhal merasakan level perkembangan manusia dan sains yang sangat menyedihkan. Ia mengamati dalam konteks UEA dan dunia Arab bahkan Islam secara keseluruhan, terdapat hubungan yang kontras antara pembangunan material dan intelektual dengan kemajuan teknologi dan ilmiah. Ia menambahkan ketika terjadi konferensi kedelapan ijaž ilmiah dalam al-Qur'an dan Sunnah tahun 2006 di Kuwait yang menghadirkan 86 pemakalah. Nidhal melihat adanya upaya yang bersifat simplistik dalam rekonsiliasi Islam dengan sains. ${ }^{21}$

Pada April 2007, konferensi yang sama diselenggarakan di Abu Dhabi mengenai "Penyembuhan Qurani". Satu tema penting konferensi tersebut adalah efek pembacaan ayat al-Qur'an terhadap air, yang konon menyembuhkan banyak penyakit pada pasien yang meminumnya, dengan alasan efek memori air. Yang lain mengatakan beberapa gelombang elektromagnetik yang berasal dari getaran-getaran al-Qur'an yang dibaca sehingga mampu mengatur ulang struktur molekul air dan memberikan energi khusus. Sebagian lagi mengatakan sistem konten informasi akan diteruskan dari al-Qur'an menuju air dan kemudian kepada pasien. Bahkan menurut Nidhal ada pembicara, seorang teknisi peralatan medis, yang membawa sebuah alat yang dapat digunakan untuk mengekstrak energi penyembuhan Qur'ani yang tersimpan dalam air yang kemudian ditransfer ke air dengan hanya menempatkan satu jari di dalamnya dan membaca ayat-ayat dengan suara keras atau di dalam pikiran seseorang. Perangkat itu menurut pembicara tersebut dapat mengubah energi menjadi informasi digital, merekamnya dan mampu mengirimkan melalui internet

\footnotetext{
${ }^{19}$ Nidhal Guessoum., xxiv

${ }^{20}$ Nidhal Guessoum, xxiv-xxv.

${ }^{21}$ Nidhal Guessoum, 13-14.
} 
kepada siapa pun yang membutuhkan di seantero dunia. Penemuan dalam konferensi tersebut dipandang sebagai lompatan kualitatif dalam perkembangan imunitas psikologis dan lompatan kuantum dalam konsep teknologi penyembuhan ajaib Qur'ani. Sebuah penemuan pertama yang menggabungkan al-Qur'an dengan teknologi modern. Menurut Nidhal semua laporan tersebut disajikan pada konferensi internasional abad 20 dan bukan dalam zaman gelap abad pertengahan. ${ }^{22}$

Nidhal selanjutnya mengatakan sistem pendidikan yang menekankan hafalan saja, termasuk sikap terhadap al-Qur'an, bahwa al-Qur'an lebih banyak dihafal saja, sehingga sebagian mahasiswa universitas lemah dalam kemampuan berfikir kritis dan analitis, sebagai buah dari sistem pendidikan di masyarakat Arab atau Islam saat ini. Pengabaian fakta-fakta dasar ilmiah yang sangat luas, diremehkannya hakikat sains, metodologi, lingkup validitas dan keterbatasan-keterbatasan di dalamnya. Walaupun sudah ada suara-suara serius yang selama bertahun-tahun untuk merekonstruksi pemahaman muslim dan interaksinya dengan sains. Tetapi suara-suara tersebut masih sedikit, terputus-putus dan seringkali sumbang bahkan untuk membuat mereka didengar apalagi mampu mempengaruhi sikap publik muslim terhadap sains. ${ }^{23}$

\section{Pinsip-Prinsip Fundamental dalam Islam}

Sebelum membicarakan wacana hubungan Islam dan sains, terlebih dahulu harus memahami prinsip-prinsip utama dalam Islam, yaitu mengenai Tuhan. Semua wacana yang berkembang dalam Islam dimulai dengan kajian mengenai Tuhan. Ayat yang penting tentang Tuhan adalah al-Ikhlas :1-4 dan al-Baqarah: 225. Konsep mengenai Tuhan sangat gamblang dan lugas. Adapun isu yang paling kontroversial mengenai aspek antropomorfis, misalnya al-Qur'an menyebutkan Allah melihat dan mendengar, yang merupakan dua dari nama-nama indah-Nya. Ayat yang menyebutkan bahwa Allah memiliki tangan, Allah berbicara kepada manusia di hari pembalasan tanpa mediator atau perantara, manusia benar-benar melihat Allah pada hari pembalasan, membuat perselisihan teologis yang serius. Nidhal berbicara mengenai ide-ide yang ditonjolkan oleh para pemikir muslim mengenai Tuhan. Ada keragaman konsep tentang Tuhan, misalnya al-Ghazali mengatakan bahwa permasalahan yang berkaitan dengan Tuhan atau dengan agama tidak dapat diselesaikan hanya dengan akal. Realitas yang kita sebut Tuhan berada di luar akal dan pikiran, sehingga sains dan metafisika tidak bisa membuktikan atau menyangkal wujud (keberadaan)-Nya. Al-Ghazali menyimpulkan keyakinan mengenai Allah hanya bisa bersumber dari pengalaman religius yang sejati, walaupun ia menolak klaim mistis yang berlebihan. ${ }^{24}$ Sedangkan kaum filsuf menganggap filsafat sebagai cara terbaik untuk mengenal Tuhan dan ilmu turunannya (paling tidak untuk kalangan terbatas). Menurut Nidhal semua filsuf mempercayai Allah dan menganggap

\footnotetext{
22Nidhal Guessoum, 5-6.

${ }^{23}$ Nidhal Guessoum, 8-9.

${ }^{24}$ Nidhal Guessoum, 25.
} 
keberadaan-Nya sangat jelas, walaupun ada hal-hal yang perlu diperdebatkan menurut mereka.

Satu abad setelah al-Ghazali muncul Ibnu Rusyd. Menurut Ibnu Rusyd filsafat bisa mensistematisasikan wacana rasional tentang Tuhan dan semua masalah penting lainnya. Bagi Ibnu Rusyd, teologi tidaklah deduktif tetapi dialektis, sedangkan wacana keagamaan klasik bersifat retoris. Argumen mengenai keberadaan Allah ada argumen kosmologis yang diperkenalkan Aristoteles dan diadopsi oleh Ibnu Rusyd, memiliki beberapa rumusan termasuk sebab pertama dan penggerak utama. Rumusan ini menegaskan bahwa keberadaan dunia dapat ditelusuri dari suatu sebab ke sebab lain, sampai kepada penyebab pertama yaitu Tuhan. ${ }^{25}$

Argumen ontologi yang dikemukakan Anselm dan Descartes menuntut adanya bukti logis. Dasar argumennya adalah kemampuan manusia membayangkan Tuhan sang pencipta memungkinkan mereka menganggapnya sebagai suatu hal terhebat yang bisa dibayangkan baik dalam pikiran atau sudah dalam realitas. Argumen teleologis, dasar argumennya ketidakmungkinan mengamati semua kerumitan, keagungan dan keselarasan dari semua ciptaan Tuhan tanpa memikirkan sosok pencipta yang sangat kuat di balik semua realitas penciptaan. Argumen moral dan kemenangan manusia dipihak yang baik yang terkadang tidak terpenuhi di dunia, memerlukan keberadaan Tuhan untuk memberi makna dan keputusan dalam kehidupan kita. Argumen spiritual adalah pengakuan beragam pengalaman spiritual yang dilaporkan manusia. ${ }^{26}$

Sains modern menurut Nidhal telah memunculkan sedikitnya tiga teori yang sangat penting dan memberi dampak yang signifikan terhadap konsepsi dan kepercayaan terhadap Tuhan. Ketiga teori tersebut adalah evolusi Darwin (melalui seleksi alam), teori kosmologi Big Bang dan Mekanika Kuantum (MK) yang merupakan deskripsi dunia mikrofisika. ${ }^{27}$

Ringkasan tentang konsep Tuhan di dunia muslim adalah tunggal, Dia adalah Pencipta dan Pemelihara alam semesta, kepada-Nya kita semua akan kembali untuk mempertanggungjawabkan perbuatan. Dia bertindak di dunia ini dan menjawab doadoa kita, Dia berada diluar imajinasi kita, namun Dia lebih dekat dari urat leher kita sendiri. Dia bisa diketahui dari cara Dia menggambarkan diri-Nya dalam al-Qur'an dan dari cara Nabi menjelaskan diri-Nya. Dalam al-Qur'an dijelaskan Dia yang Indah namun misterius. ${ }^{28}$

\section{Sains dan Beberapa Kritik}

Terdapat kontroversi antara kubu ilmuwan konservatif garis keras yang mempercayai objektivitas dan universalitas upaya ilmiah dan kubu filsuf dan sosiolog

${ }^{25}$ Edith Hall, "'Master of Those Who Know': Aristotle as Role Model for the Twenty-First Century Academician," European Review; Cambridge 25, no. 1 (February 2017): 3-19, http://dx.doi.org/10.1017/S1062798716000429.

${ }^{26}$ Nidhal Guessoum, Islam Quantum Question, Reconciling Muslim Tradition and Modern Science, 34.

${ }^{27}$ Nidhal Guessoum, 39-40.

${ }^{28}$ Nidhal Guessoum, 45. 
liberal sains yang mempercayai sifat relatif dan aspek sosial dari penelitian ilmiah dan hasil-hasilnya. Apa itu sains, bagaimana sains bekerja, hingga batasan-batasan dan kelemahan-kelemahannya. ${ }^{29}$

Menurut Nidhal sebagian besar kaum elite dan masyarakat pada umumnya memiliki sifat apresiasi yang kurang bagaimana sains bekerja dan seberapa banyak capaian yang harus dihasilkan setiap harinya dalam level yang cukup besar dan kepercayaan yang terlalu besar terhadap hampir semua jenis klaim dari apapun sumber rujukannya meskipun ia hanya berasal dari surat kabar, tv atau orang terhormat. Masyarakat tidak memahami kriteria falsifikasi untuk mengecek ilmiah tidaknya sebuah hipotesis, begitu pula tentang peer review atau wide checking dalam menerima atau menolak hasil penemuan. Masyarakat juga sama sekali tidak memberikan apresiasi terhadap peran sains dalam memperkuat rasionalitas dan tradisi berpikir kritis dalam penalaran para pemikir kita, baik dalam isu ekonomi, sosial maupun agama. Untuk menjawab keresahan tersebut Nidhal memulainya dengan mempertanyakan apa itu sains. Menurut Nidhal selama ini belum ada konsensus mengenai apa itu sains. Beberapa ahli seperti Rutherford mengatakan sains adalah apa yang dilakukan oleh ilmuwan.

Sains menurut Nidhal adalah upaya manusia untuk membangun penjelasan objektif mengenai dunia sekitarnya. Dalam upaya untuk membuat penjelasan objektif yang berarti tujuan tersebut tidak mudah dicapai. Karena sains dibangun manusia, maka kemungkinan salah atau bias selalu ada dan sains adalah upaya menggambarkan dunia seluas mungkin. ${ }^{30}$ Sains adalah seperangkat metode objektif, sistematis, kuantitatif dan dapat difalsifikasi, sehingga memungkinkan seseorang mengamati alam semesta.

Filsafat sains menurut Nidhal adalah pengujian kritis terhadap metode penelitian dan eksplorasi yang digunakan dan diterapkan dalam sains. ${ }^{31}$ Kesadaran ilmiah diawali bahwa metode deduksi yang diwariskan dari filsafat harus diubah menjadi induksi. Seseorang harus memulai dari fakta dengan keyakinan-keyakinan apapun mengenai fakta tersebut, kemudian mencoba membangun generalisasi, yakni induksi suatu hukum sesuai dan bisa menjelaskan fakta. Sebagaimana Roger Bacon menemukan metode ini, al-Biruni dan Ibnu Sina yang hidup 3 abad sebelum Bacon juga menggunakannya. Karakteristik utama dan terpenting sains terletak pada metode dan proses yang dibangun didalamnya dan menuntut kepatuhan siapapun yang bekerja di dalamnya yang disebut dengan metode ilmiah.

Deskripsi diatas menurut Nidhal harus dilengkapi dengan memasukkan unsur manusia dimana elemen-elemen subjektif berpeluang dalam membangun hipotesa dan pembuktiannya, dan perlunya komunitas ilmiah dalam memperkuat proses tersebut. Selanjutnya Nidhal berpandangan bahwa sains yang dikembangkan oleh peradaban kuno (ketika mereka menganggap alam sebagai kerajaan dan pertempuran

\footnotetext{
${ }^{29}$ Nidhal Guessoum, 67.

${ }^{30}$ Nidhal Guessoum, 71-72.

${ }^{31}$ Nidhal Guessoum, 82.
} 
dewa-dewa), seperti masyarakat Cina, Maya, India dan Babilonia, Yunani, Romawi, dan Arab-Muslim adalah bagian dari usaha saintifik. Walaupun para penulis Barat cenderung mengatakan renaisans (khususnya revolusi Copernicus dan kemenangan paradigma Galileo) sebagai awal mula sains. Berbeda dengan pemikir muslim yang mengatakan dasar-dasar sains sudah ada sejak paradaban Arab-Muslim. ${ }^{32}$

Bagaimana sains bekerja dan bagaimana menyadari keterbatasan otoritasnya dalam kasus-kasus tertentu dijelaskan tiga filsuf sains, yaitu Popper, Thomas Kuhn dan Paul Feyerabend. Popper memperkenalkan karakteristik hipotesis ilmiah yang harus bisa difalsifikasi dengan cara membuat beberapa prediksi atau harus bisa mengasah pada konsekuensi yang dapat diuji dan dibuktikan benar atau salahnya. ${ }^{33}$ Setiap hipotesis yang tidak dapat diuji atau dibantah dianggap tidak ilmiah. Popper mengajak ilmuwan untuk mengajukan hipotesisnya. Namun menurut Nidhal dalam ilmu alam ada juga ruang gelap dimana sejumlah entitas dalam alam semesta telah diperkirakan keberadaannya, namun tidak bisa dibuktikan secara langsung, misalnya quark dan materi gelap. Meski demikian tidak ada orang yang meganggap teori fisika tersebut tidak ilmiah walaupun keberadaannya tidak dapat dibuktikan. Demikian pula dalam teori-teori kosmologi yang memprediksi eksistensi alam semesta yang tidak dapat dibuktikan secara eksperimental. Dengan demikian menurut Nidhal kriteria falsifiabilitas sangat penting dan amat menentukan dalam hipotesa ilmiah, dan bisa menemukan jalan buntu dalam kasus tertentu. Gagasan falsifiabilitas sendiri menurutnya merupakan konsep paling tajam untuk mendifinisikan dan menggarisbawahi sifat aktivitas ilmiah. ${ }^{34}$

32Okasha dalam Philosopy of Science mengkaji Sejarah Sains mengatakan bahwa asal-usul kebohongan sains modern terjadi pada periode 1500-1750, yang sebenarnya penyelidikan ilmiah sudah dilakukan sejak zaman kuno dan abad pertengahan, sehingga revolusi ilmiah tidak datang tiba-tiba begitu saja. Pada masa awal tersebut, pandangan Aristotelian sangat dominan. Namun gagasan Aristoteles termasuk metode penyelidikannya tampak asing bagi ilmuwan modern. Dengan kata lain ilmu pengetahuan modern dimulai sejak Galileo, sebab sains sebelum itu tidak sesuai dengan metode ilmiah ala Galileo. George Sarton menulis dalam Introduction to the History of Science, menyajikan sains selama periode Islam. Ia mengatakan tidak ada perkembangan dalam sejarah sains baik modern ataupun Barat tanpa memanfaatkan kontribusi tersebut. Walaupun Chittick mengatakan sains modern tidak muncul di kalangan Islam karena pandangannya bahwa sains modern menolak teleologi mengabaikan yang transenden. Ziauddin Sardar mengatakan umat Islam telah mengembangkan setidak-tidaknya dasar-dasar dan spirit sains modern dengan menekankan seruan yang berulang-ulang disebutkan dalam al-Qur'an dengan mengamati dan merenungkan fenomena alam sebagai cara untuk mengenal Allah atau ketetapan-ketetapan-Nya. Gagasan-gagasan Ibn Haitam, al-Biruni dan Ibnu Sina serta para ilmuan muslim lainnya telah menjadi dasar semangat ilmiah dikalangan muslim. Teolog klasik kata Sardar menekankan eksprementasi dan observasi sistematis sebagaimana metode ilmiah yang ada sekarang. Sardar mengatakan dari Islamlah Eropa belajar melakukan penalaran logis, metode eksperimen, ide-ide kedokteran dan menemukan kembali filsafat Yunani. Lihat Nidhal Guessoum, 75.

${ }^{33}$ Arnold G. Kluge, "Explanation and Falsification in Phylogenetic Inference: Exercises in Popperian Philosophy," Acta Biotheoretica; Leiden 57, no. 1-2 (June 2009): 171-86, http://dx.doi.org/10.1007/s10441-009-9070-4.

${ }^{34}$ Olivier Rieppel, "Popper and Systematics," Systematic Biology; Oxford 52, no. 2 (April 2003): 259-71, https://search.proquest.com/docview/194768761/abstract/5AE7E17ACF6C43E9PQ/6., 83-84,136. 
Menurut Thomas Kuhn dalam The Structure of Scientific Revolution, sains bergerak ke depan, sains muncul menghapus teori-teori yang ada, sebuah paradigma digantikan dengan paradigma yang lain. ${ }^{35}$ Ketika paradigma geosentris mendominasi berabad abad dan kemudian digantikan dengan paradigma heliosentris. Namun Kuhn mengatakan transformasi tersebut berjalan sangat subjektif dan sering bergantung pada apresiasi para ilmuwan terhadap anomali-anomali yang beredar serta kesiapan masyarakat untuk memegang teguh atau membuang teori lama. Klaim objektifitas dan universalisme sains menurut Kuhn adalah fatamorgana. Pendapat Kuhn dibantah oleh Imre Lakatos, filsuf sains kelahiran Hongaria. Ia mengatakan bahwa paradigma tidak identik dengan teori individu. Paradigma terbentuk melalui proses kolektif, yang dapat menjamin objektifitasnya. Ia menyarankan semacam research program berangkat dari rangkaian fakta untuk menghasilkan penemuan baru. Sedangkan Paul Feyerabend, filsuf Austria berpandangan tidak ada pendekatan tunggal dalam memperoleh pengetahuan yang harus dibakukan sebagai metode ilmiah. ${ }^{36}$

Postmodernisme (1960-1970) juga mengkritik sains. Postmodernisme diidentikkan dengan relativisme. Gagasan ini mengandaikan sains salah satu pendekatan untuk mencari pengetahuan dan untuk melihat dunia diantara pendekatan-pendekatan lain yang setara secara esensial, misalnya mistisisme dan okultisme. Zaman postmodernisme menandai munculnya gerakan-gerakan sosial yang melontarkan kritik pada sains, misalnya enviromentalisme, mengkritik penerapan sains dan metodenya. Rachel Carson dalam buku Silent Spring menggambarkan bahaya besar sains bagi dunia (lingkungan). Sebagai ahli zoologis ia memaparkan dampak lingkungan yang terjadi di Amerika Serikat. Demikian pula semua orang mengetahui dampak negatif teknologi seperti polusi udara, air, hujan asam, kepunahan spesies, limbah beracun, penyebaran kanker, pemanasan global dan banyak lagi. Sardar mengatakan sains Amerika dikontrol secara ketat oleh aliansi militer, perusahan multinasional yang kuat dan riset dari berbagai universitas, termasuk riset dan tesis mahasiswa dikendalikan militer. ${ }^{37}$ Sardar menyebut Sains sebagai teologi kekerasan dan menjelaskan sains melakukan kekerasan terhadap subjek pengetahuan, objek pengetahuan, pemanfaatan pengetahuan bahkan pada pengetahuan itu sendiri. Sains di Barat juga dituduh mendiskriminasi gender dalam upaya ilmiah, dimana harus ada kesetaraan partisipasi dalam program penelitian dan aktivitas ilmiah. Kemudian kritik sentrisme budaya dimana klaim sains dianggap berakar dari norma, aturan dan metode Barat. Menurut Sardar sains modern menjadi alat kontrol dan manipulasi kebudayaan non-barat, meminggirkan minoritas dan perempuan. Demikian pula kegiatan ilmiah sengaja dibiarkan tertutup untuk orang

${ }^{35} \mathrm{~K}$. Brad Wray, "Assessing the Influence of Kuhn's Structure of Scientific Revolutions," Metascience; Dordrecht 21, no. 1 (March 2012): 1-10, http://dx.doi.org/10.1007/s11016-011-9603-8.

${ }^{36}$ Nidhal Guessoum, Islam Quantum Question, Reconciling Muslim Tradition and Modern Science, 84.

${ }^{37}$ Nidhal Guessoum, 87-89. 
non-Barat berdasarkan rasio jurnal yang diindeks di Barat terhadap jurnal di seluruh dunia. ${ }^{38}$

Isu metafisik mengenai sains menjadi tema perdebatan para ilmuwan, filsuf dan agamawan mengenai perihal batas-batas epistemik sains. Saintisme berpandangan penerapan sains untuk semua hal yang ada di alam semesta, termasuk kehidupan manusia dan masyarakat. Sebagian mengemukakan sains teistik, sebuah kecenderungan untuk mengembalikan Tuhan kepada sebuah pandangan dunia dan pendekatan sains. Teisme adalah kepercayaan kepada Tuhan, bukan hanya sebagai pencipta dan perancang dunia, tetapi juga penopang alam semesta, sehingga tanpaNya alam semesta mustahil terjadi. Sedangkan deisme, Tuhan hanya dibutuhkan dalam penciptaaan alam, selanjutkan hukum-hukum alam mengambil alih peran Tuhan dan mengarahkan setiap detil alam semesta. Mehdi Golshani memfokuskan wacananya pada sains teistik dan menganjurkan pergeseran dari sains sekular, bahwa sains teistik sesuai dengan filsafat sains Islam dan para pemikir Barat. Sains teistik ini menurut Nidhal dapat memberikan jalan keluar dari barbagai krisis saintifik (etika, lingkungan, sosial dan lain-lain)

Selanjutnya Nidhal mengusulkan membuat sintesis atau perpaduan antara prinsip-prinsip teistik dan berbagai metode/temuan sains modern dengan merumuskan beberapa teologi baru yang konsisten dengan sains modern meskipun sains modern tidak senada dengan keyakinan dan teks suci secara literal. ${ }^{39}$ Kemudian membangun kosmologi untuk memungkinkan ditemukannya beberapa spririt dalam alam semesta dan keberadaannya. Sebuah kosmologi modern Islam menurutnya sangat mungkin dibangun selama para aktor intelektualnya tetap terbuka, kreatif dan tidak kaku, baik dalam pengetahuan religious maupun saintifiknya. ${ }^{40}$

Perlunya mengajarkan filsafat sains, merevisi dan menyajikan sejarah sains dengan benar, melakukan dialog yang serius dengan para teolog dan cendikiawan muslim untuk meyakinkan bahwa sains dewasa ini sudah terlalu lama mereka monopoli, perlunya mendidik publik tentang isu-sisu sains yang agak dekat dengan wilayah keagamaan dan membangun dialog dengan Barat. Adanya permasalahan kependidikan dan kemasyarakat yang serius dalam Islam, keberatan para ulama untuk memberikan kepada para pakar non agama) untuk menyuarakan gagasan tentang isu apa pun yang diklaim milik ranah keagamaan, dan kedang kala budaya ilmiah di kalangan muslim pada umumnya dan absennya kultur tersebut dalam pengajaran para ulama.

\section{Tawaran Rekonsiliasi Agama dan Sains}

Sebelum mengajukan gagasannya, Nidhal mengkritik pola-pola Islamisasi yang berkembang saat itu. Diantaranya model i'jâr al-ilmî. Model pemikiran ini

38Ziauddin Sardar, Islamic Science The Way Ahead (Makalah Konferensi Tabun 1995), Dalam Ebsan Masood (Ed), How Do You Know? (London-New York: Pluto Press, 2006).

${ }^{39}$ Nidhal Guessoum, Islam Quantum Question, Reconciling Muslim Tradition and Modern Science., 97-

98.

${ }^{40}$ Nidhal Guessoum, 370-371. 
menyatakan bahwa al-Qur'an jika dibaca dan ditafsirkan secara ilmiah akan secara eksplisit mengungkapkan sebagian kebenaran ilmiah, karena al-Qur'an berisi segala jenis pengetahuan. Gagasan ini dijustifikasi ayat al-Qur'an: "Tiada kami alpakan sesuatu apapun di dalam kitab" (al-An'am (6): 38). Metode ijấz ini berkembang di dunia Arab. Banyak buku ditulis dengan pendekatan ini untuk menunjukkan bahwa al-Qur'an telah meramalkan misalnya penemuan telpon, telegram, radio, televisi, faximili, e-mail, laser, lubang hitam dan sterusnya. Konferensi pun digelar demi mengokohkan pendekatan ini. ${ }^{41}$

Zahlul al-Najjar sebagai tokoh metodologi ini mematok 10 prinsip pendekatan i'jâa, yaitu: Pertama, memahami teks al-Qur'an dengan baik sesuai dengan pemaknaan Bahasa Arab. Kedua, mempertimbangkan al-ulum al-Qur'ân. Ketiga, menghimpun berbagai ayat yang berkaitan dengan sebuah topik umum sebelum melangkah pada penafsiran baru. Keempat, menghindari penafsiran berlebihan dan tidak memelintir ayat-ayat agar bisa sesuai dengan temuan ilmiah. Lima, menjauhi isuisu yang gaib. Enam, fokus pada sebuah tema secara khusus ketika menafsirkan ayatayat yang berhubungan dengan topik tertentu. Tujuh, mempertahankan ketetapan dan kejujuran intelektual ketika berhadapan dengan pernyataan ilahi. Delapan, menggunakan fakta-fakta ilmiah yang sudah mapan, bukan teori yang belum pasti atau dugaan Sembilan, membedakan tafsir al'ilmî dan i'jâz al-ilmî, baik dalam alQur'an maupun sunnah. Tafsir al-'ilmî ada beberapa kasus yang belum bisa dipastikan hasilnya oleh ilmu-ilmu manusia, sehingga sah-sah saja menggunakan teori ilmiah untuk menjelaskan ayat atau hadis. Sedangkan dalam i'jâz al-'ilmî, seorang penafsir menggunakan fakta-fakta ilmiah yang benar-benar mapan saja. Sepuluh, menghormati upaya-upaya ulama sebelumnya dalam segala hal terkait. ${ }^{42}$

Menurut Nidhal pedoman tersebut agak trivial dan tidak fundamental, terlalu kaku secara metodologis. Dalam kenyataannya praktisi i’jâz justru tidak berpegang pada metode tersebut. Ia menggambarkan bagaimana an-Najjar menggunakan metode ini. An-Najjar memilih sebuah ayat kosmik (pernyataan al-Qur'an tentang bagaimana fenomena alam), menyajikan belasan halaman berisi informasi ilmiah yang dapat ditemukan pada ensiklopedi mananpun, baru kemudian menyatakan bahwa benar-benar ada keajaiban ( $i j a \hat{a})$ karena ayat tersebut telah meramalkan semua fakta ilmiah sebagaimana ia menafsirkan. ${ }^{43}$

Nidhal mengkritik prinsip-prinsip ijâz ini yaitu pertama, sangat normatif dan tidak fundamental. Prinsip yang ditawarkan tidak berbeda dengan aturan metodologis

${ }^{41}$ Nidhal Guessoum, 148.

${ }^{42}$ Nidhal Guessoum, 156-157.

${ }^{43}$ Contoh Ketika An-Najjar menafsirkan ayat al-An'am (6): 1), Segala puji bagi Allah yang tela menciptakan langit dan bumi dan mengadakan gelap dan terang. Ayat ini ditafsirkan dalam 13 halaan dari berbagai referensi klasik diikuti 8 halaman mengenai skenario Big Bang dengan berbagai tahap secara detail: quark, gluon, usia nucleon dan anti nucleon serta usia galaksi. Penjelasan selanjutnya adalah mengenai kegelapan meliputi kegelapan primordial alam semesta, kegelapan kosmos, kegelapan kedalaman laut dan Samudra, kegelapan dalam Rahim, kegelapan dalam alam kubur. Menurut Nidhal benar-benar diluar jangkauan pemikiran bagaimana ayat tersebut bisa ditafsirkan demikian. Lihat Nidhal Guessoum, 163.

Kharanah, Vol. 19 (1), 2021 
akademik yang berlaku di kampus pada umumnya. Kedua, pedoman terkait penggunaan teori-teori yang sudah mapan. Yang jadi pertanyaan apakah pendukung teori ijâz menganggap teori gravitasi Isaac Newton adalah fakta alam yang sudah mapan. Padahal pembahasan mengenai teori gravitasi sudah dimulai sejak zaman Yunani Kuno sehubungan dengan kinematika sistem tata surya. Einstein juga membahas mengenai relativitas umum sebagai sebuah teori geometri mengenai gravitasi. Apakah teori Einstein juga mapan, mana yang harus dipilih dan atas dasar apa. Ketiga, kalau kemapanan sebuah fakta atau teori dikaitkan dengan ayat al-Qur'an, berarti an-Najjar membiarkan para peneliti menggunakan ayat demi mengunggulkan suatu teori sains tertentu, dan ini adalah kesalahan luar biasa. Keempat, klaim kelompok ini yang mengatakan seseorang dapat mengidentifikasikan fakta ilmiah untuk kemudian membandingkan dengan pernyataan yang jelas dalam al-Qur'an menunjukkan kesalahpahaman yang nyata dengan sifat sains. Sains menurutnya bukanlah sekumpulan fakta seperti halnya sebuah rumah bukan sekedar sekumpulan batu bata. Kelima, klaim bahwa penafsiran al-Qur'an bersifat tunggal dan pasti sehingga bisa dibandingkan dengan pernyataan ilmiah. Sains bersifat sederhana dan jelas, yang berisi fakta definitif yang mudah dibedakan dari teori. Keenam, prinsipprinsip metodologis yang diajarkan ternyata jarang digunakan dalam praktiknya. ${ }^{44}$

Model ijmâlî Ziauddin Sardar, seorang ilmuwan muslim asal Inggris kelahiran Pakistan didasarkan dua ide: (1). Bahwa sains modern telah mengalami cacat bawaan dan berbahaya, baik dalam dasar metafisikanya maupun aplikasi teknologinya. (2). Islam sangat mendorong pengembangan sains tetapi tetap haus memperhatikan etika, nilai moral dan harmoni dengan lingkungan. Dengan kata lain pengembangan sains dalam Islam seperti bentuk ibadah yang mempunyai fungsi spiritual dan sosial. ${ }^{45}$

Menurut Sardar pengembangan sains islami dalam pendekatan ijmâlî harus memiliki kreteria: tidak reduktif, tidak anakronistik, tidak ada dominasi metodologi tertentu atau pembatasan metodologi tertentu, tidak terfragmentasi dan terspesialisasi, tidak berwawasan sempit, tidak bersifat objektif yang lepas dari konteks sosial, tidak Bucailistik, tidak bersifat mistik, tidak tanpa keadilan dan tidak berdasar worldview Barat. ${ }^{46}$

Untuk membentuk sains ideal yang dimaksud, Sardar mematok beberapa konsep fundamental yang menjadi kerangka kerja ilmiah yaitu: tauhid, keterkaitan alam dengan Tuhan, khilafah, adanya tanggungjawab dan akuntabilitas kerja, sains bagian dari ibadah, ilmu dan sains bagian dari jalan menuju Allah, halal vs haram konsep untuk menilai penerapan ilmu, keadilan vs kezaliman konsep untuk menilai aplikasi sains, manfaat vs ketidakbergunaan pertimbangan lain untuk mengukur aplikasi sains. ${ }^{47}$

\footnotetext{
${ }^{44}$ Nidhal Guessoum, 117.

${ }^{45}$ Ziauddin Sardar, Explorations in Islamic Science (London-New York: Mansel, 1989), 112.

${ }^{46}$ Nidhal Guessoum, Islam Quantum Question, Reconciling Muslim Tradition and Modern Science.

126.

${ }^{47}$ Nidhal Guessoum, 127.
} 
Secara teoritis, menurut Nidhal konsep integrasi sains versi ijmâlî menjadi model yang menjanjikan. Namun dalam kenyataannya, gagasan tersebut hanyalah mimpi dan tidak terealisasikan. Alasannya adalah: Pertama, pendukung model ijmali sudah bubar sebelum ide terealisasikan. Kedua, kelompok ini sering menentang sebuah teori tetapi tidak memberikan alternatifnya. Ketiga, ajakan Sardar untuk menghindari penyiksaan atau pembedahan binatang dalam pengembangan sains justru dinilai penyebab kelambatan dalam perkembangan sains. Karena riset maju dengan mengandalkan percobaan pada binatang. Secara keseluruhan model Ijmâli Sardar bagus dalam tataran konsep tetapi tidak dapat diteruskan dalam upaya mempertemukan antara sains dan agama.

Sedangkan integrasi ilmu Ismail Raji al-Faruqi mendasarkan pengetahuan atas dua premis: (1) kegagalan reformis Islam untuk melahirkan peradaban yang nyata. (2) Kegagalan para kritikus post modernis Barat untuk menjauhkan dunia modern dari berbagai bencana, khususnya kehancuran agama dan hilangnya makna serta tujuan hidup. ${ }^{48}$ Al-Faruqi sebenarnya ingin mengkritik realitas pengetahuan modern yang sekularistik satu sisi dan Islam yang terlalu religius pada sisi yang lain dalam suatu paduan yang utuh tanpa pemisahan satu sama lain. ${ }^{49}$

Menurut Nidhal, ada beberapa catatan gagasan Islamisasi al-Faruqi ini, pertama, proyek al-Faruqi yang mencari kesesuaian khazanah Islam kepada sains modern dinilai sebagai pengarahan Islam kepangkuan Barat, sehingga Islam hanya bersifat pasif. Kedua, proyek Islamisasi ini sebagaimana juga dikemukakan Sardar dikhawatirkan akan menyebabkan penghapusan dan penyaringan pengetahuan yang dianggap tidak islami, sehingga menciptakan kasta para ilmuwan yang akan menyaring pengetahuan yang diinginkan kelompok mereka saja. Ketiga, proyek Islamisasi dinilai tidak sesuai dengan kenyataan sejarah paradaban Islam. Dalam sejarah para ilmuwan klasik tidak mengislamkan paradaban sebelumnya, sebaliknya mereka mempelajari, menguasai dan mengembangkan ilmu dengan metode ilmiah ang berlaku, bukan dari perspektif agama. ${ }^{50}$

Menurut Nidhal prinsip utama filsafat pengetahuan dalam al-Qur'an adalah manusia dianugerahi kemampuan untuk belajar dan memahami sesuatu. Kemampuan inilah yang menjadikannya khalifah di muka bumi. Konsep 'aql (reasoning) muncul 49 kali dalam al-Qur'an dan selau disajikan dalam bentuk aktif, bukan sebagai gagasan abstrak atau kemampuan pasif manusia. Pada prinsipnya manusia bisa mempelajari apapun, hal ini berarti alam semesta juga dapat dipahami, karena pengetahuan bersifat luas, menyeluruh dan meliputi berbagai bidang. ${ }^{51}$

\footnotetext{
${ }^{48}$ Nidhal Guessoum, 117.

${ }^{49}$ Rosnani Hashim and Imron Rossidy, "Islamization of Knowledge: A Comparative Analysis of the Conceptions of AI-Attas and AI-Fārūqīi," Intellectual Discourse 8, no. 1 (2013), http://journals.iium.edu.my/intdiscourse/index.php/islam/article/view/479.

${ }^{50}$ Nidhal Guessoum, Islam Quantum Question, Reconciling Muslim Tradition and Modern Science, 124.

${ }^{51}$ Nidhal Guessoum, 54.
}

Kharanah, Vol. 19 (1), 2021 
Pengamatan terhadap al-Qur'an yang berhubungan dengan pengetahuan dan cara memperolehnya memungkinkan ditemukannya beberapa istilah yang merujuk pada hierarki metode pengetahuan itu sendiri. Beberapa diantaranya adalah mendengarkan, mengamati, merenungkan, berfikir, mempertimbangkan, merefleksikan, dan lain-lain yang disebutkan belasan kali dalam al-Qur'an. ${ }^{52}$ Oleh karena itu manusia dapat memeras saripati ilmu pengetahuan dari ayat-ayat al-Quran dengan tingkat pengetahuan yang berbeda-beda sesuai dengan perbedaan makna istilah pengetahuan itu sendiri, seperti mempercayai, mempertanyakan, berfikir, memahami, menyadari, memastikan dan lain-lain.

Menurut Nidhal, al-Qur'an juga menekankan perhatian bahaya penalaran tanpa bukti berbahaya. ${ }^{53}$ Bukti menurut sudut pandang al-Qur'an menurut Ghaleb Hasan adalah bukti yang meyakinkan atau argumen yang jelas dan kuat. Bukti tidak didapat dari tradisi atau pandangan orang-orang terdahulu. ${ }^{54}$ Baik pernyataan atau penolakan sama-sama memerlukan bukti. ${ }^{55}$ Sedangkan tujuan pengetahuan menurut al-Quran adalah naiknya jenjang manusia dari sekedar percaya menuju jenjang yang lebih tinggi, yakni mengetahui, membaiknya moral dan keyakinan penuh akan keberadaan Tuhan.

Menurut beberapa penulis, sekitar 750 ayat al-Qur'an yang berhubungan dengan fenomena alam. Sebagian dari ayat-ayat tersebut sangat mendorong bahkan merekomendasikan kajian dan eksplorasi tentang alam semesta. ${ }^{56}$ Dengan memusatkan perhatian, melakukan observasi dan berfikir ekstensif pada fenomena astronomis, seseorang dapat membuktikan keesaan Tuhan dan mengenal sang pencipta lebih dalam, begitu juga dengan kebijasanaan dan desain halus-Nya.

Menurut Nidhal filsafat sains al-Qur'an mengacu pada dua hal, pertama: eksplorasi alam, mulai observasi hingga penelitian yang serius, menunjukkan keteraturan dan tujuan kosmos. Kedua: kajian terhadap alam semesta harus mengarah pada satu kesatuan tertentu yang menuntun pada keimanan terhadap sang pencipta. ${ }^{57}$ Para pemikir muslim tetap mempertahankan dimensi etis dalam sains al-Qur'an dan Islam pada umumnya. Namun, konsep sains dalam pengertian modern memang tidak mudah ditemukan dalam al-Qur'an atau bahkan disebagian besar warisan Islam klasik.

Dalam hal ini Nidhal mengemukakan satu pendekatan dalam rekonsiliasi agama dan sains yaitu dengan model kuantum, sebagai berikut:

1. Prinsip tidak bertentangan

${ }^{52 N i d h a l ~ G u e s s o u m, ~} 55$.

${ }^{53}$ Departemen Agama RI, Alquran Dan Terjemahnya (Bandung: Sinar Baru Algensindo, 2011). Lihat QS. Al-Isra (17): 36, "Dan janganlah kamu mengikuti hal-hal yang kamu tidak mengetahui apapun tentangnya."

${ }^{54}$ Departemen Agama RI. Al-Maidah (5): 104.

${ }^{55}$ Departemen Agama RI. An-Nisa (4): 174.

${ }^{56}$ Departemen Agama RI. Lihat al-Imran (3): 191.

${ }^{57}$ Nidhal Guessoum, Islam Quantum Question, Reconciling Muslim Tradition and Modern Science, 59. 
Dalam proses filosofi rekonsiliasi antara agama dan sains, Nidhal berpegang pada pemikiran Ibnu Rusyd ${ }^{58}$ yang mengatakan dalam kitabnya Fashl al-Maqâl bahwa agama dan filsafat (yang disebut sebagai hikmah atau kebijaksanaan yang dapat diperluas menjadi pengetahuan, termasuk sains) tidak pernah bisa bertentangan satu sama lain karena keduanya adalah saudara sepersusuan (bosom sisters). Keduanya hanya mengungkapkan kebenaran yang sama dengan cara yang berbeda. Ibnu Rusyd secara eksplisit menyerukan penafsiran metaforik atas teks-teks agama dengan berlandaskan al-Imran (3): 7, dalam rangka mempertemukan kontradiksi antara pernyataan agama dan hasil penalaran pengetahuan profan mengenai masalah tertentu. Hermeneutika Ibnu Rusyd menurut Campanini ${ }^{59}$ mengajak pada takwil linguistik yang memposisikan konsep atau makna dibalik kata-kata. Karena ayat al-Qur'an memiliki makna yang beragam, ada yang bermakna literal, sebagian lagi bermakna simbolis tentang alam semesta. ${ }^{60}$ Disamping itu penekanan keragaman bacaan dan makna dibalik ayat-ayat al-Qur'an sebagaimana disarankan Muhammad Talbi dan Hasan Hanafi.

Jika al-Qur'an diseriusi dan dikaji sedemikian rupa, prinsip-prinsip Rusydian tentang ketidakmungkinan adanya konflik antara firman Tuhan dan karya Tuhan harus dijunjung tinggi. Prinsip ini dapat menjadi suatu pendekatan tanpa penolakan atau tanpa oposisi ketika seseorang mengemukakan mengenai gagasan tertentu, bukan dengan membuktikan bahwa teori ini ditemukan dalam al-Qur'an, tetapi

${ }^{58}$ Mengapa Ibnu Rusyd, menurut Nidhal ada 4 alasan menjadikan Ibnu Rusyd sebagai model dalam rekonsiliasinya: (1). Ibnu Rusyd adalah tokoh yang cerdas. Pada usia 12 tahun telah menguasai tiga bidang keilmuan yang berbeda, yaitu fiqih, sains dan kedokteran, disamping jasanya dalam meletakkan dasar-dasar teologi dan pemikiran filsafat Islam.(2). Pengaruhnya yang besar pada pemikiran sesudahnya, khususnya dalam bidang sains, teologi dan filsafat, Ibnu Rusyd berjasa membersihkan tafsiran-tafsiran sebelumnya yang dinilai keliru untuk kemudian menjelaskannya agar bisa dihasilkan interpretasi yang benar, memberikan doktrin baru bahwa logika bukan hanya bicara benar salah, tetapi juga harus berkaitan dengan logika empirik. (3). Upaya Ibnu Rusyd untuk mempertemukan agama dan filsafat, wahyu dan rasio, yang menurut Nidhal dilakukan Ibnu Rusyd dengan pertama: menganalogikan filsafat dengan agama sebagai bosom sister (saudara sepersususan), sehingga luka agama yang disebabkan filsafat adalah luka paling perih karena berasal dari orang terdekat. Kedua: prinsip agama tidak bertentangan dengan filsafat, siapapun yang akan mencari kebenaran dari agama akan selaras dengan filsafat. Ketiga: menggunakan metode takwil ketika secara tekstual sebuah ayat tampak tidak selaras dengan pemahaman rasional. Keempat: hukum ilahi adalah kemanunggalan wahyu dan akal. Lihat Khodari Soleh, "Pendekatan Kuantum Dalam Integrasi Agama Dan Sains," 122-125.

${ }^{59}$ Campanini menyimpulkan bahwa teks-teks agama tidak berbeda dengan teks linguistik pada umumnya dan bisa dijadikan objek analiis hermeneutik, maka secara otomatis al-Qur'an tidak dapat dimaknai secara literal semata. Berbagai petunjuk biologis dan kosmologis al-Qur'an memang tidak benar-benar ilmiah. Namun secara simbolis, petunjuk-petunjuk tersebut dapat diinterpretasikan dengan hermeneutika tekstual yang cerdas. Sistem linguistik al-Qur'an terdiri atas teks-teks tetap, tetapi niat para penafsir dapat mengungkapkan sejumlah makna, hermenutika filosofis bisa melacak dasar sains dalam al-Qur'an tanpa harus berasumsi bahwa al-Qur'an adalah teks ilmiah, lihat Masimo Campanini, "Qur'an and Science: A Hermeneutical Approach," Journal of Qur'anic Studies 7, no. 1 (2005). 60

${ }^{60}$ Nidhal Guessoum, Islam Quantum Question, Reconciling Muslim Tradition and Modern Science, 61.

Kharanah, Vol. 19 (1), 2021 
dengan menunjukkan bahwa sebuah pembacaan dan interpretasi cerdas terhadap ayat-ayat tertentu telah menghasilkan kesimpulan yang sepenuhnya konsisten dengan teori ilmiah tertentu yang relevan.

\section{Penafsiran berlapis}

Penafsiran terhadap ayat-ayat al-Qur'an harus dilakukan secara berlapis, berjenjang sesuai dengan tingkat penalaran seseorang, sehingga tidak ada penafsiran tunggal. Pembacaan berlapis ini menjadi keniscayaan karena tingkat nalar manusia memang berbeda. Dengan penafsiran berlapis upaya untuk mempertemukan antara agama dan sains menjadi sangat terbuka. ${ }^{61}$

Konsep sains dalam pengertian modern tidak mudah ditemukan dalam alQur'an atau bahkan sebagian besar warisan Islam klasik. Nidhal menunjukkan sikapnya: (1) Menolak terhadap semua perspektif yang ekstrem, yaitu klaim seputar pengetahuan ilmiah (mukjizat ilmiah) dalam al-Qur'an harus ditolak karena berbagai alasan. (2). Menekankan pembacaan berlapis (multiplicity readings), dengan nuansa dan petunjuk multilevel terhadap sebagian besar -jika tidak semua- bagian al-Qur'an-. Pembacaan al-Qur'an dengan berbagai perangkat termasuk, pengetahuan ilmiah yang dimilikinya. Pendekatan ini merupakan pendekatan kombinasi dari gagasan beberapa cendikiawan, mulai dari Ibnu Rusyd hingga Muhammad Talbi. Menurut Nidhal alQur'an harus dibaca dan dikaji dengan serius dan penuh hormat, maka resep hermeneutika dan prinsip Rusydian (Averoes) mengenai ketidakmungkinan pertentangan antara firman Tuhan dan karya Tuhan haruslah dijunjung tinggi. Dalam praktiknya, prinsip ini dapat diubah menjadi pendekatan tanpa keberatan atau tanpa oposisi yang memungkinkan kita meyakinkan masyarakat muslim mengenai gagasan tertentu. Contoh teori evolusi Biologi, bukan dengan membuktikan bahwa teori tersebut dapat atau tidak dapat ditemukan dalam al-Qur'an melainkan dengan mengajak mereka melakukan pembacaan dan penafsiran yang cerdas terhadap beberapa bagian al-Qur'an yang benar-benar konsisten dengan teori tersebut. ${ }^{62}$

Prinsip ini didasari beberapa alasan yaitu pertama, sebagaimana Sachiko Murata dan William Chitticck menyatakan secara historis munculnya keragaman pemahaman atas ayat-ayat al-Qur'an justru menjadi kekayaan intelektual dalam sejarah keemasan Islam. Sebagaimana yang diungkapkan ad-Dzahabi bahwa munculnya banyak penafsiran, mulai yang tekstual sampai yang rasional, empirik dan mistik. Setiap mazhab mempunyai tafsir sendiri untuk menguatkan pendapatnya.

Alasan kedua, umat Islam menempatkan al-Qur'an sebagai kitab suci, dan selalu merujuk ayat-ayat al-Qur'an untuk membahas topik-topik yang dianggap penting. Aslan mengatakan umat Islam dari semua ragam kebudayaan dan etnis, harus membaca al-Qur'an dalam Bahasa Arab, karena ia merupakan kata-kata suci Tuhan dan memiliki kekuatan spiritual dengan istilah barakah. Ciri lain yang membuat al-Qur'an istimewa adalah kualitasnya yang mengagumkan dalam versi

${ }^{61}$ Nidhal Guessoum, 62.

${ }^{62}$ Nidhal Guessoum, 174-175. 
aslinya yang berbahasa Arab, kekayaan kosa kata, beberapa kata memiliki beberapa arti, kekhasan dalam nada dan irama, keseimbangan dalam menyentuh pikiran dan hati, menggunakan gaya sastra dan ilmiah sekaligus, dan keluasan dalam menggunakan imaji dan metafora sebagaimana disebutkan oleh Fahd ar-Rumi dalam Characteristic of the Noble Quran. Bahkan Muzaffar Iqbal menyebut al-Qur'an sebagai sebuah filsafat sains kosmologis, karena al-Qur'an mengandung beberapa ayat yang menggambarkan asal mula alam semesta dan kehidupan. ${ }^{63}$

Ketiga, pernyataan al-Qur'an sendiri yang menunjukkan adanya ragam pemahaman dan pemaknaan atas sebuah teks (QS al-Imran (3): 7). M. Asad menyatakan ayat 7 al-Imran ada banyak ekspresi dalam al-Qur'an yang tidak dapat dipahami secara tekstual melainkan harus dipahami dalam arti alegoris, agar dapat dipahami masyarakat yang berbeda.

Keempat, Nidhal mengutip pendapat Sachiko Murata dan Chittick yang mengutip sabda Rasul bahwa setiap ayat al-Qur'an mengandung tujuh arti, mulai tekstual sampai makna ketujuh, makna terdalam yang hanya diketahui Allah sendiri. Muhammad Talbi mengatakan ada banyak kunci dalam memahami al-Qur'an, kuncikunci tersebut dalam waktu yang sama bisa menjadi objektif atau subjektif. ${ }^{64}$

Kelima, mengikuti pendapat Ibnu Rusyd mengenai nalar manusia. Menurut Ibnu Rusyd tingkat berfikir masyarakat tidaklah sama, ada awam, menengah dan elit. Awam adalah kelompok yang hanya berfikir tekstualis-retoris sama sekali tidak mampu berfikir rasional. Kelas menengah adalah kalangan yang mampu berfikir rasional tetapi belum mampu tingkat kritis filosofis. Kelompok elit adalah kalangan yang mampu berfikir kritis filosofis tidak sekedar rasional dialektis. Karena itu menurut Ibn Rusyd pada dasarnya tidak ada kewajiban untuk memahami teks sesuai dengan makna zahirnya secara keseluruhan atau memahami teks sesuai dengan makna takwilnya secara keseluruhan. ${ }^{65}$

3. Pendekatan falsifikatif teistik.

Prinsip ini terkait dengan persoalan metodologis dan pilihan metafisis yang diikutinya. Menurut Nidhal, ini adalah salah satu cara kerja sains terkait metodologi. Aspek ini memberi aturan main bagaimana sains bekerja. Dengan menggunakan kriteria falsifiabilitas. Sains bukanlah sebuah proses mekanis, sebab ia dimulai dari prinsip-prinsip yang terkadang belum terbukti dan sering tidak bisa dibuktikan, bahkan cenderung bergantung pada insting pribadi, kecenderungan personal, konsensus bersama dan mengikuti berbagai paradigma serta prinsip-prinsip revolusi yang aktual. ${ }^{66}$

${ }^{63}$ Nidhal Guessoum, 48-50.

${ }^{64} \mathrm{Nidhal}$ Guessoum, 50.

${ }^{65} \mathrm{Ibnu}$ Rusyd, Fashl Al-Maqal Fi Mä Baina al-Syariah Wa al-Hikmah Min al-Ittisal (Beirut: Dar al-Afaq, 1978), 31.

${ }^{66}$ Nidhal Guessoum, Islam Quantum Question, Reconciling Muslim Tradition and Modern Science, 175.

Khazanah, Vol. 19 (1), 2021 
Secara sederhana, metode ilmiah yang dianut dalam sains dapat diartikan dengan serangkaian tindakan yang terdiri atas beberapa tahapan: (1) serangkaian tindakan mengamati fenomena dan merekam sebanyak mungkin data/informasi tentang fenomena tersebut. (2) membuat hipotesa berdasarkan pengetahuan yang sudah ada terhadap fenomena tersebut. (3) menguji hipotesa, kemudian memperbaiki/menyempurnakan hipotesa sehingga prediksi yang dibuat terbukti benar atau membuang hipotesis lama dan menggantinya dengan hipotesis baru jika bertentangan dengan hasil percobaan atau pengamatan. ${ }^{67}$

Nidhal mengusulkan agar pengembangan sains modern harus didasarkan atas worlview teistik. Teisme bukan sekedar kepercayaan kepada Tuhan sebagai pencipta semesta, tetapi juga penopangnya, dimana tanpa-Nya keberadaan semesta menjadi mustahil terjadi. Tuhan senantiasa berinteraksi dengan semesta, tidak lepas darinya. Metode pengembangan sains modern harus didasarkan atas metode ilmiah yang ketat, yaitu falsifikasi, tetapi pada aspek metafisikanya didasarkan atas worldview teistik, sehingga gabungan keduanya menjadi falsifikatif-teistik.

Nidhal Guessoum adalah tokoh yang ikonik dan memiliki otoritas dalam upaya membangun hubungan harmonis antara agama dan sains. Nidhal seorang praktisi saintis dan pada saat yang sama memiliki ghirah keislaman yang kuat, yang berkomitmen membangun sains dari diskursus Islam. Nidhal sangat terobsesi dengan Ibnu Rusyd yang berusaha untuk mendapatkan legitimasi agama terhadap filsafat, dengan kata lain Ibnu Rusyd berpihak pada filsafat untuk menaklukkan agama. Nidhal menyatakan solusi hubungan antara agama dan sains dengan menindaklanjuti apa yang diungkapkan oleh Ibnu Rusyd, dengan mengatakan bahwa filsafat tidak bertentangan dengan Islam. Padahal Nidhal dan Ibnu Rusyd memiliki titik tolak yang berbeda. Nidhal menyatakan solusi hubungan antara sains dan agama adalah dengan bertitik tolak dari al-Qur'an dengan pendekatan kuantum yaitu antara sains dan alQur'an idak ada pertentangan, penafsiran berlapis terhadap al-Qur'an dan falsifikasi teistik. Akan lebih baik jika Nidhal tetap konsisten dengan solusi problem hubungan antara Islam dan sains tersebut, karena memiliki titik tolak yang berbeda dengan apa yang telah dirintis oleh Ibnu Rusyd.

\section{Simpulan}

Upaya rekonsiliasi antara agama dan sains yang dikemukakan Oleh Nidhal Guessoum berangkat dari kritiknya terhadap kondisi pendidikan dan masyarakat Arab dan dunia Islam secara keseluruhan. Juga terhadap pemikiran-pemikiran yang berkembang mengenai hubungan antara agama dan sains yang terkadang terlalu simplistik, baik model ijmâlî Sardar, model ijjâz an-Najjar, maupun Islamisasi pengetahuan model al-Faruqi. Menurut Nidhal solusi hubungan antara sains dengan agama menggunakan metode kuantum yaitu: Pertama, prinsip tidak ada pertentangan antara agama dan sains. Keduanya hanya mengungkapkan kebenaran yang sama dengan cara yang berbeda.

${ }^{67}$ Nidhal Guessoum, 72. 
Kedua, penafsiran berlapis terhadap al-Qur'an, misalnya ketika membahas teori evolusi, bukan dengan membuktikan bahwa teori tersebut dapat atau tidak dapat ditemukan dalam al-Qur'an, melainkan dengan melakukan pembacaan dan penafsiran yang cerdas pada beberapa bagian al-Qur'an yang benar-benar konsisten dengan teori mereka.

Ketiga, falsifikatif teistik. Nidhal berusaha untuk mengembangkan paradigma yang teistik dalam sains, sehingga bisa dikembangkan oleh nonmuslim sekalipun selama ia meyakini adanya satu bentuk kreator atau pencipta yang selalu aktif dalam relasi dengan semesta, sehingga dualisme antara pencipta dan semesta selalu dalam relasi dinamis dalam cara kerja saintifik.

\section{Daftar Pustaka}

Abdullah, M. Amin. Multidisiplin, Interdisiplin \& Transdisiplin, Metode Studi Agama \& Studi Islam Di Era Kontemporer. Yogyakarta: IB Pustaka, 2020.

Abidin, M. Zainal. "Islam Dan Ilmu Pengetahuan: Diskursus Pemikiran Muslim Kontemporer." ULUMUNA 10, no. 2 (2006): 391-410.

Abidin, Muhammad Zainal. "Dinamika Perkembangan Ilmu Dalam Islam Serta Statusnya Dalam Perkembangan Peradaban Modern." Jurnal Ilmu Ushuluddin 11, no. 1 (2012): 21-42.

Ben-Zaken, Avner. "The Heavens of the Sky and the Heavens of the Heart: The Ottoman Cultural Context for the Introduction of Post-Copernican Astronomy." British Journal for the History of Science; Nomvich 37, no. 132 (March 2004):

https://search.proquest.com/docview/215730323/abstract/6831679491C24 83EPQ/17.

Departemen Agama RI. Alquran Dan Terjemahnya. Bandung: Sinar Baru Algensindo, 2011.

Groot, Kees de. "The Church in Liquid Modernity: A Sociological and Theological Exploration of a Liquid Church." International Journal for the Study of the Christian Church 6, no. 1 (March 1, 2006): 91-103. https://doi.org/10.1080/14742250500484469.

Hall, Edith. "'Master of Those Who Know': Aristotle as Role Model for the TwentyFirst Century Academician." European Review; Cambridge 25, no. 1 (February 2017): 3-19. http://dx.doi.org/10.1017/S1062798716000429.

Hashim, Rosnani, and Imron Rossidy. "Islamization of Knowledge: A Comparative Analysis of the Conceptions of AI-Attas and AI-Fārūqū." Intellectual Discourse 8, no. 1 (2013). http://journals.iium.edu.my/intdiscourse/index.php/islam/article/view/479 
Ian G. Barbour. When Science Meets Religion: Enemies, Strangers, or Pathners? New York: HarperCollins, 2000.

Ibnu Rusyd. Fashl Al-Maqä FīMāBaina al-Syariah Wa al-Hikmah Min al-Ittisal. Beirut: Dar al-Afaq, 1978.

Ilyas Daud. "Islam Dan Sains Modern (Telaah Pemikiran Nidhal Guessoum Dalam Karyanya Islam's Quantum Question Reconciling Muslim Tradition and Modern Science." Jurnal Al-Mutaaliyah, 2019.

Khodari Soleh. "Pendekatan Kuantum Dalam Integrasi Agama Dan Sains." Jurnal Ulul Albab Volume.19, no. No.1 (2018).

Kluge, Arnold G. "Explanation and Falsification in Phylogenetic Inference: Exercises in Popperian Philosophy." Acta Biotheoretica; Leiden 57, no. 1-2 (June 2009): 171-86. http://dx.doi.org/10.1007/s10441-009-9070-4.

M. Amin Abdullah. Multidisiplin, Interdisiplin \& Transdisiplin, Metode Studi Agama \& Studi Islam Di Era Kontemporer. Yogyakarta: IB Pustaka, 2020.

Maimun Syamsuddin. Integrasi Multidimensi Agama Dan Sains: Analisis Sains Islam Naquib al-Attas Dan Mehdi Golshani. Yogyakarta: IRCiSoD, 2012.

Masimo Campanini. "Qur'an and Science: A Hermeneutical Approach." Journal of Qur'anic Studies 7, no. 1 (2005).

Nidhal Guessoum. Islam Quantum Question, Reconciling Muslim Tradition and Moderm Science. London-New York: I.B. Tauris, 2011.

Wray, K. Brad. "Assessing the Influence of Kuhn's Structure of Scientific Revolutions." Metascience; Dordrecht 21, no. 1 (March 2012): 1-10. http://dx.doi.org/10.1007/s11016-011-9603-8.

Zainal Abidin Bagir (ed). Integrasi Ilmu Dan Agama: Interpretasi Dan Aksi. Bandung: Mizan Media Utama, 2005.

Ziauddin Sardar. Explorations in Islamic Science. London-New York: Mansel, 1989. - Islamic Science The Way Ahead (Makalah Konferensi Tahun 1995), Dalam Ehsan Masood (Ed), How Do You Know? London-New York: Pluto Press, 2006. 